

\author{
special \\ COLlections \\ DOUGLAS \\ LIBRARY \\ queEN's university \\ AT RINGSTON \\ RINGSTON ONTARIO CANAOA
}






\section{CONSIDERATIONS $\mathrm{ON} T \mathrm{THE}$}

\section{Prefent State}

O F

$A F \mathbb{F} \mathbb{R} S$ $I N$

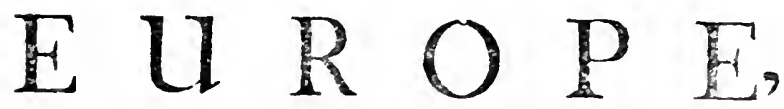

And particularly with Regard to the Number of Forces in the Pay of Great-Britain.

The SECOND EDITION.

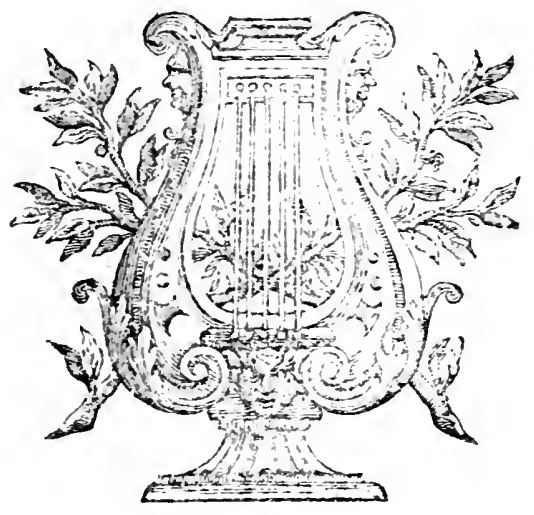

\section{$L O N D O N:$}

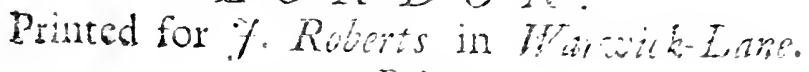
1730. Pise Is. 


$$
\text { AC911,730, } 66
$$




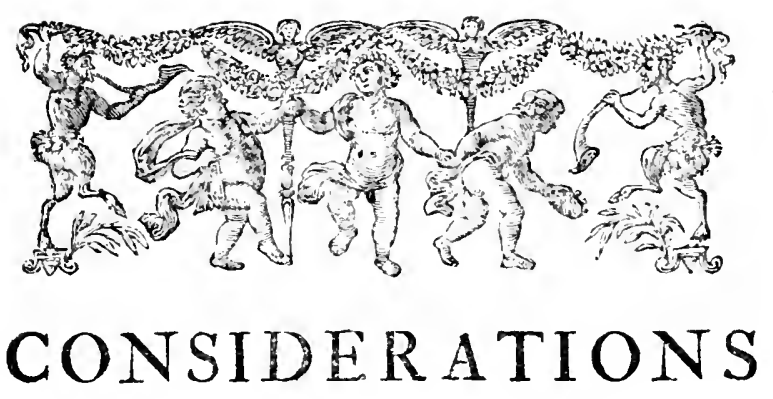

$\mathrm{ON} \mathrm{T} \mathrm{HE}$

\title{
Prefent State of Affairs
}

\author{
I iv
}

\section{$E U R O P E$, \&c.}

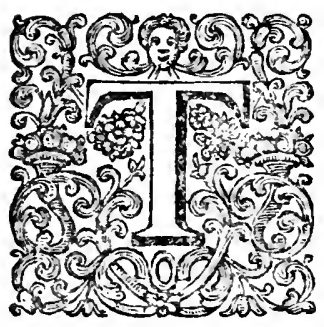

$\mathrm{HE}$ Clamours inautrioully - raifed againt the Number of Forces, and particularly the He/ians, which this Nation has of late Years from the Situation of $A$ fitairs been obliged to maintain; have determined me to examine impartiaily, whethor the Augmentation and Continuation of the Forces in our Pay, Briti/i or A Foreigners, 


\section{$(6)$}

Foreigners, beyond what was ufual in Time of Peace, was a wife, juft, and neceflary Meafure, in confequence of Treaties made for the Interctt of Great Britain, and the Prefervation of the Peace and Balance of Europe, independent of any other Intereft and Confideration whatfoever.

In order to put this Matter in a true Light, I thall firt take a fhort View of the State of Affairs that occafioned the making of thofe Ireaties, and the Augmentation of Forces in confequence of then.

That the Treaty of Vienne, concluded between the Emperour and Spatin in May' 1725 , was the only Soure and Foundation of all the Troubics that have diftracted Europe for fome Years pat, muft be allowed by all; and there is as little Reafon to doubt, but that the Delign of laying a Foundation for a formidable Power in Europe, by the Union of the two Families, was the chief Motive that induced thofe Powers to make and fupport, if polfible, this 'Treaty, preferable to all other Views, and at the Hazard of all other E.ventis.

As foon as that Treaty was concluded, the Aecethon was demanded of England and Hulland by the Emperour, in a peremptory

Nanner, 
Manner, and the Refufal of the Acceffion was follow'd with undeniable Proofs of a Defign to deprive us of fome of our Poffeffions; and both the Dutch and us, of fome of our moft valuable Privileges of Trade; and even to ftrike at the prefent happy Eftablifhment of the Crown.

No fooner was that Treaty ratify'd, but Spain required the immediate Reftitution of Gibraltar, as a Condition of Peacc and Commerce between the two Crowns; and made no Scruple, at the fame time, to declare publickly their Refolution to fupport the Emperour by Force, in Maintenance of the Oftend Trade and Company. Various Intrigues and Projects were fet on foot at the fame time in Favour of the Pretender. And all this was done witheut any Provocation on the Part of Great Britain, or without any Foundation for a Quarrel; or the leaft Pretence for a Complaint, fo much as alledged by the Allies of the Treaty of Viema againft the Conduct of the late King.

He was engaged in no Treatics that could give the leaft Offence either to the Emperous or Spain, nor had taken any Steps that could difoblige or provoke the Refentment of cither of them : He had acted as an impartial Mediator at Camuraj, by Virtue of the Quadruple Alliance, for the Prefervation of

the 


\section{(8)}

the Peace; and had done nothing in Breach of the particular Treaty of Friendfhip and Commerce made between him and Spain, in 1721. And therefore, however defirous their Imperial and Catholick Majefties might be to become Friends, and make up their Differences between themfelves; there could not be the leat Pretence for their doing it at the Expence of England or Holland, as it plainly appeared thcy did by the Nature of jected

Such undoubted Evidences in Facis of concerted Defigns againt the Interefts of this Nation, not to fay any thing of the Secret Articles belonging to that Treaty, called upon his Majetty, to ftrengthen himfelf with fuch Counter-Alliances as might enable him to difappoint or defeat thofe Deligns.

An Alliance with Holland, whofe Intercit in mon $R$ cfpects is infeparable from that of En? Wh, was ccrtainly the mott natural and obviousonthis Oecalion : But the Conttitution of that Republick makes it almoft impollible to keep a Negociation fecret there; and the Situation of thcir Country, with Refpect to the Emperour, might expofe them, before they could be fufficicntly fupported, to his Refentment, for cntring into a Negociation in Oppofition to his Meafures. Was it not therefore the molt advifable Step for the common 


\section{(9)}

common Gook of both Nations, that Englund, being more immediately concerned in the dangerous Confequences of the Tienna Trea$t y$, and farther removed from the fiffects of any fudden Retentment, thoukt firlt ttrengthen herfelf with fome other conliderable l'owers, whofe Intercti it is to check the imperial Power, by an Alliance, to which the Acceftion of the States might afterwards become eafy and fecure?

Accordingly, the Treaty of Hanower, between England, France, and Prufia, was concluded the $3 \mathrm{~d}$ of Septemuer 1725. And whatever particular Reafons may have determined his Pruffiun Majefty to withdraw himfelf from that Alliance; yct, confidering with what a jealous Eye the Houfe of Aufria hath all along looked upon the Increafe of Dominions in the Fanily of Brandenburg, and how incompatible the real Interetts of thefe two Courts are, the engaging the King of Prufia into the Treaty of Hanorer, was in it felf a right Meafure, and had for fome time the defired Effect.

And whatever Clamours may have been rais'd againft an Alliance with France, as being unnatural to England, it was certainly in this Cafe, being made in Oppolition to. the Meafures and Power of the Emperour, the moft natural Alliance Englaud could have. 
The Animofities and Friendhips oetween other Powers, may, according to new Incidents and Circumftances, frequently vary; but the Oppoitition between the Emperour and Fraince, muft be conitunt in all Junctures and Events. 'They may be in l'eace fometimes, and have the Appearance of Firiendthip; but there mult ever ycmain a Jealoufy ai bottom, and fecret Rivalhip between them, and an unalterable Desiro in ene to check the ambitions View's of the other: This hath ever been, and in all l'robability will ever be the Cate, as long as thofe two lowers, of Aufria and Bourlon, continue to be fo balanced, with refpect to one another, as they are at prefent, and fo fuperior in Strength, as each of them is, to any other Power befides.

But fuppofing France was not a proper Ally againit the Treaty of Vecmu, for preferving the Rights and Polfotions of Great Britgin, for which I will allow that France abftractedly might have no great Concern; yet as this Treaty was the Bond of a trrict Union between the Emperon and Spain, and as that Union was founded upon the Profpect of Warriages between the Intints of Span and the Arh-lututhefices, it must necefiarily creat: the greateft Alarm and Unealincts to Irane ; for frulu thofe Marriages have been 


\section{I )}

accomplingd, they would have occafion'd an entire Separation in Interest and friendlhip of Spantrom France, and the Death of one particular runce might have render'i the Houfe of Alfar mure powertil and formiable than ever, bytne Re-uniun of Dominions that were once to terrible to that of Bourlon; and therefore, as long as the Union between the Emperour and Spatin fubizted, on the liews aborementioned, Fulice, on Account of her own Interet. was the lower with which England might haty, and ought even preterably to any other, to mats an Allince at that Juncture, in ordar to obviate and defeat the dangerous Deligins of the Fiemu Treaty: For france could never hope to compals the Diflolution of an Union fo prejudicial to her, without refolving at the fane time to be faithifl to her Lngagements, in fupport of the Intercti of thote tho thould be united with her in the fime Caule.

This being the Situation of Afrzirs, the late King would have been wanting, in a due Concern for the Good of this Nation, for the Balance of Europe, and for the Dignity of his Crown, had he not fortificd himfelf with the Troaty of Flanere, in Oppolio tion to that of Itenial the pernicious Confequences of which, with relpect to the Polfolions and Trade of Great Eritam, B 3

wore 


\section{( 12$)$}

were alieady but too evident: But his Unwillingnefs to involve his Subjects in a War, and to put them to ail extraoridnary Expence, by any unnecefliry Precultions, made him content himfelf, at the opening of the Parliament on the 2cth of famury $1725-6$, with acquainting thon with his having made this defentive Allianci; without demanding more than the fame Forces that were employcl before thefe Troubles began, which were Ten 'Thoufand for the Sca Service, and Eightecr Thoufand Landmen.

In the mean time, the Confequences of the Fienin Traty began to fhew themfelves openly, and the formidable Effects of it to be telt in molt Parts of Europe; the Emperour found Means to detach the King of Pruffia, who hath a ltanding Force of about Seventy Thoufand Mien, from the Hanover 'Treaty. Great Remittances of Money were made from Madria to Vienna. Á Plan was framed for an extraordinary fugmentation of the Imperial Forces with between Thirty and Forty Thoufand Men: And Negociations were warmly pufhed in various Courts, both in the Empirc, and the North, for hiring great Bodies of Troops. Thefe Negociations fucceded fo well, by the Help of Sublidies from Spain, that fome of the Eiectors, and other Princes of the Empire, engaged 


\section{( I 3)}

engaged to furnilh about Twenty Seven Thoufand Men; and the Czarina having acceeded to the Viema Treaty, agreed to find a Body of Thirty Thoufand Nien for the Service of the Emperour and Spatiin.

Thefe vigorous and warlike Preparations on the part of thofe Powers, to make themfelves formidable on all Sides, did necetarily obiige the Hanover Allies to concurt the proper Meafures for their mutual Defence, and for preventing a new $W$ ar being kindled in Europe. Any further Delays, to provide for Action, would have been dangerous; and his Majefty had Recourie to his Purliament, for increaing the Number of Scamen, and for Allowance for fuch extraordinary Expence as the Service might require, which was agreed to by an Addreis of the Houfe of Commons on the 25th of March I726; who defired him, not only to increase bis Number of Seamen, but to concert fuch other Meafures, as would beft conduce to the $S_{e-}$ curity of the Trade and Navigation of this Kingdom, and the Prefervation of the Peace of Europe; with Affurances, that they soculd effectually make good all fuch Expences and Engagements, as frould be made for outaining thofe great and defirable Euds. 


\section{(14)}

At this Juncture, and in Confequence of the Meafures concerted between his Majetty and his Allies, the late King agrced with the Landgrave of Hefle Caffel for a Body of Twclve Thoufand Heffians, to be ready to march for his Majefty's Service upon Demond.

Fiance likewife increafed their Forces, for the Sake of the Common Caure, with about. 'Thirty Thoufand Men : And gave Orders for raifing Sixty Thoufand Militia to garrifon their Towns, by which they might be enabled to march all their Regular Troops into the Ficld, amounting to near One Hundred and Sixty Thoufand Men.

In the mean time; the Hanover Alliance having been communicated to the States Generil, they acceeded to it; and in Confequence of this Accertion, the Dutch imnicdiately procecded to an Augmentation of their Troops, which they increafed from about Thirty Thoufand to above Fifty Thoufand Men; requiring at the fame Time that England and France would have their refpective Quotas of 'Twelve Thoufand Men in Readinefs and at Hand for the Defence of the R.cpublick, in Cafe of an immediate Attack; which they had more Reafon to apprehend than any of the Allies, on Ac-
count 


\section{( IS)}

count of their Situation, with Refpect to the Imperial Garrifons in the Low Countries on one Side, and of their being expofed on the other to the Forces of the King of Pruffia, who had been lately gained by the Empcrour.

This equitable Demand on the Part of the States could hardly have been anfivered by the King, it he had raifed no' Troops but in England. The Dutch are too well acquainted with the Accidents of the Sea, and the Difficultics and Delays which attend the Tranfporting great Bodics of Troops, to depend upon fuch Help in a Cafe, which if it happened at all, would be fudden and too quick to be withitood by flow Movements. The View of this made it neceffary to have Foreign Troops properly placed; and the having them was the only Thing that enabled the King to do Juftice to his Allies on this Occalion, by promiling the Dutch that the Twelve Thoufand Heffians taken into his Pay, thould march, in Cafe of need, to their Affitance; and the French agreed to have as many of their Swifs Troops on the Side of Fianders for the fame Service.

While the Imperial Negociations fuccecded fo well in the Empire and the North, the Application of the Hanover Allies, for fecuring 


\section{(15)}

curing the Courts of Sweden and Denmark to their Interett, was no lefs fuccefsful: Sweden acceeded to their Treaty, and befides their Quota of Five Thoufand Men, agreed to have a Body of Ten Thoufand Mien ready for the Common Caufe; in Confideration of Fifty Thoufand Pounds, to be paid for three Years by France, and as much by England.

About the fame Time, the Convention of Denmark was finithed, by which that Crown engaged to have a Body of Twenty Four Thoufand Men, ready to be reinforced with Six Thoufand more; for the Expence of which, France agreed to pay a Sublidy of 350,000 Rixdollars per Anmun for four Years; and in Cafe of a War, to take Twelve Thoufand of them into their actual Pay. His Majefty, as Elector, promifed Twelve Thoufand Men to join the Twenty Four Thoufind Dines, and to have likewife Twelve Thoufand more for a Reinforcement. By the fame Treaty, France ftipulated to furnifh Thirty Thoufand Men, as Occalion fhould require, for the Service of the Allies, in the Empire or the North.

His Majefty's Land-Forces in England. were augnented this Year with about Eight Thonland Mcin; and he likewife encreated his 


\section{(I7)}

his Electoral Troops from Sixteen Thoufand to Twenty Two Thoufand Men.

But here perhaps it will be asked, What hath Great Britain to do with this String of Foreign Troops? What have we to apprehend from the Forces of Pruffa, Mufcowy or the Emperour? What Good can the Swedes, the Danes, the Hefians, or Hanoverians do us? It was our Bulinefs to lie by, to wait, and fee the Coniequences and Events of the Vienna Traty, and to take our Mcafures accordingly at a proper Seafon. This indeed would have becn a very prudent Step, if the Terms of the Viema Treaty, and the Meafures taken, and the Forces raifed in Confequence of it, by the Contracting Parties, had not been directly levelled at the Intereft of Great Britain: "This would be a very plaulible Doctrine, if the Pofiefioms of Givoulter and Port Mithon, if the Trade to Italy and spain, to the Eaft and IrefIndies, and the Baltick; if the Bulance of Europs, and the prefent happy Eftablitument, were become indifferent Things to this tion; as indeed one would think they were, efpecially the laft, by the Weekly Licentious Writings of fome Gentlemen, who would be thought to be Mien of no little Confequence. But as I do not believe that the Nation is yet grown quite weary of the Bcrefit 


\section{( I 8 )}

Benefit of Foreign Trade, of of the Reig of the prefent Royal Family over us; and as thofe effential and valuable Points were ftruck at, fome by the very Terms, and others by the immediate Confequences and Secret Articles of the "Trcaty of Tiema, I am perfuaded that cren thofe, who clamour fo loudly againit what has been done, would have ccnfured the Adminitration, as guilty of the greatcft Indolence and Folly, had they neglected to make the Treaties, to concert the incafures, and provide the Forces above-mentioned, for the Security of our happy Eitablihment, for the Prefervation of our Rights and Poffefions, and of the Peace and Balance of Eirope.

Lct us now take a fhort View of the State of the Confederate Forces, as they ftood ranged on one Side or the other, in Favour of the Treaties of Viema or Hanover, in the Year I 727 ; when the Prcliminaries were figned.

The Augmentation of the Emperour's Forces by Recruits, or additional Troops, was between 'Thirty and Forty Thoufand Men, which made his whole Nuuber Two Hundred Thoufand. By the Treaties he had made with the Electors of Bararia, Palatine, Cukgne and Trevos, and other Prin- 
ces of the Empire, he had fecured to his Service about Twenty Seven Thoufand Men; and by the Alliance with the Czarina Thirty Thoufand. He hal likewife engaged the King of Praffac in his Intcret, who has an Army of Screnty Thoufand Men.

The Forces of Spain might be reckoned to be about Sixty 'Thoufind Men, befides their Naval Power.

On the other Sike, Great Britain had increafed her Land Forces from about Eighteen Thoufand to about Twenty Six Thoufand Men; which was an Augmentation above the Complement we had before the Troubles began, of about Eight Thoufant Men only. The Parliament likewife voted for this Year's Service Twenty Thoufand Seamen; which being computed into the Service of the preceeding Ycar, when only Ten Thoufand Men were voted, though more were employed, it may be reckoned that we employed Five Thoufand more Scamen each Year, than in Time of Peace. Befides our Land and Sea Forces at Home, the Twelve Thoufand Hefians were continued in our Pay.

The Frencls had augmented their Regular Troops with about Thirty Thoufand Men, C. 2 whis's 


\section{(20)}

which increafed their whole Army to about an Hundred and Sixty Thoufand Men. They had likewife filled their Nagazines, and provided Artillery and all forts of Ammunition ready for taking the Ficld; they had alfo got a difiplined Militia of about Sixty Thoufand Nen, and they fitted out for the Seat Service of this Year Twelve Men of Nar.

The Dutch, from their Accelfion to the Treaty of Haciover, in the Year 1726, had increafed their Forces from about Thirty Thoufand to above Fifty Thoufand Men; an Augmentation of about Twenty Thoufand beyond what they had in Time of Peace: And they had likewife made Preparations to fit out Eighteen Men of War.

The Qnota of Sweden, by Virtue of their Treaty, was Five Thoufand Men, and they were alfo to have ready on Demand Ten Thoufand Men more, by Virtue of a Sublidy to be paid for three Years by England and France.

By the Cenvention with Demmark, that Crown was to provide a Body of Twenty Four Thoufand Men, to be reinforecd with Six Thoufand more, for a Subfidy paid by Eamince for four Years.

The 
The King, as Elector, had increas'd his Troops, from Sixteen Thoulind to Twenty two Thoufand Men.

By this State of the Forces on each Side, it is plain, that the Meafures and Motions of the Hanower Allies, gradually attended the Motions and Meafures of thofe of Vienna; that their Counfels were prudent and iteady; that they did not provoke and precipitate a War on one Hand, while they took Care on the other, not to be forced, for Fear of a War, and for Want of timely Preparations, into bafe and difadrantageous Terms. It is no lefs evident, that the Forces provided by Great Britain, were no more than a fuitable Contingent, in Proportion to the Forces provided by the reft of the Allies engaged in the fame Caufe.

Thus Matters ftood in 1727 , when almolt all the Powers of Ettrope were directly or indirectly engaged, and ranged on the Side of the Treaty of Vicnua or Hanceer.

The Meafures of the firt had been fo well concerted, by the early Remittances of great Sums of Money from Madrid to Vienzia, by the Accelfion of fo many Princes, by the Acquifition of fuch a Number of Forces in 
the Fimpire, and the North, that their Inperial and Catholick. Majerties thought their Plan for uniting their Families, and for laying the Foundation of a formidable Power in Europe, could not fail. They imagined, that Erigland and Holland, deftitute of Friends, exhaulted by former Wars, apprehenfive of loling their Trade and Polfellions, threatned on one Side by the Forces of the Emperour, and on the other by thofe of Spain, muft have acceeded to their Treaty, and have ferved to ftrengthen and confirm their Schene of exorbitant Greatnefs. But when the unnatural and incompatible Alliance, as it hath been called, between England and France, came to be fortified by the Accetion of the States, and of other confiderable Powers; when a proportionable Number of Forces, in Oppolition to thofe of Viemna and Madrid, were provided; when a Plan of Operations was framed, and the Allies appeared ready to take the Ficld for their mutual Defence, and for preferving the Peace and Balance of Europe; while at the fame time the Galleons (the great Refource for fupporting the vait Defigns of the Empcrour and Spain) were detained in the Weft-Indies; the Imperial Minifters began to change their Lan-guage and Views : 'They would not venture to employ the Troops they had raifed and hired, in beginning a War; nor fecond Sparz 


\section{(23)}

in the Sicge of Gibraltar, by making an offenfive Diverfion in other Parts; and therefore they caufed Infinuations to be made to the Hanover Allics, of their Defire to have Matters accommodated in an anicable Manner: That it fhould be agreed in general, to put Things on the Foot they were before the making of the Treaties of Vicmua and $\mathrm{Ha}$ nover; and that whatever Differences remained between the contracting Parties, or their refpective Allies, hould be adjufted by Way of Negociation at a Congrefs.

A Plan of Preliminarics was accordingly framed by the Hanover Allies, and fent to Vienna; the Emperour agrecd to fign them in May' 1727 , without ftaying for the Confent and Approbation of Spain; which parcd the Way, as it naturally muit do, for the Diffolution of the Alliance between his Imperial Majerty and the King of Spain.

By this Mcans a Stop was put to all Hotilities in Europe. But Spain being provoked at thefe Steps towards a gencral Pacification, and having entertained forne finall Hopes of Difturbances in England on account of the late King's Death, thought fit to difpute the Execution of fome of the Articles relating to Trade; and confequently Hoftilities ftill continued between that Crown and England 


\section{( 24 )}

in the Weft-Indies, which prevented the Mecting of the Congrefs. However, England did not llip this Opportunity of diminilhing their Expence; tor immediately upon the ligning of the Preliminaries, Three thoufand tour hundred twenty eight Men were fent back to Ireland; while the Allies ftill kept the fame Number of Forces on Foot.

This Difpute with Spain continued till March 1728, when by the Steadinefs and Union of the Allies, the was brought to comply; and by an AEt figned the 6th of that Nonth, $N . S$. all the Difficulties that retarded the Execution of the Preliminaries were removed; and in Confequence of it, the Congrefs was opened at Soifforns the 16 th of fune following.

Thefe were the happy Effects of the Treaty of Hanover, and of the prudent Meafures and Preparations thereupon; a War that threatned all Europe was prevented, and a Foundation laid for bringing about the Diffolution of the formidable Union between the Emperour and Spain.

Here perhaps it may be asked, Why were not all the Troops, Domettick or Foreign, in our Pay, beyond the ufual Complement in time 


\section{$(25)$}

time of Peace, difcharged afer the ITar was prevented, the l'reliminaries figned and no tified, and the Congris openal ? What turther Occalion was there for any exrerdinary Forces? In Anfuer to this Cuction, another may be asked; What did Eirgha?, or indeed any other Country ever get by laring down Arms, al Hobanding Forces, in order to make leace? 'I hey have very hort Memories who have rorget the Contequences of fuch a Conduct; but in the pretent Care, the Reafons will appear trill ftronger, it we obferve the Circumitinces and Nature of this Congrefs. Other Congrelles were generally allembled after a Har, in which the Superiority and Succelo of Arms on che Side, had difpofed the other to fue for Peace, and confequently made tho conquering Party Matar of the Negoctutions: So that as focn as the Preliminaries were once Etrted, there was little to be done but to raiuse them into a

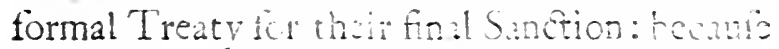
the Fate of Arms had put the weakert Sida under a Neceinev to linmic, in thole Noirts which had beon conteftad and eccafunce the War. But in this Cate, where cach sitz had only made Prepartions tor a VIar; where Fortune had not decided the Coute for either; both Parties nict at the Crispis upon an equal Foot to conntonance and lupport their refpotive Pretenfions, and it was 


\section{(26)}

eafy to be conceived, that neither Side would be lo wakk and imprudent, as to venture to difarm, and by that Mfeans being naked and defencelclis, give the Adverfary the Advantage of ciebating his Pretenfions Sword in Hand: And confcquently, as the Emperour and his Allies continued to keep up the fame Number of forces as they had before the Congreis, Eingluid, Firance, and Holland were obliged to do the fame. And this is the plain Reaton why the Parliament, notwithtanding the figning of the Preliminaries, and the Necting of the Congrefs at Soiffers, wicly reted for the Years 1728 , and 1,20 , Twenty two thouland rine hundred tity fire Land Forces, and the Contiruniton of the 'Iwelve Thoufand Hefforns. Anc indeced it would bave been a mort dithonourabie and whing l'art, with refpect to our Allics, as well as the weaket that could have becn acted with refpect to our own Intereft, if we hat ofterit ou diminifh the Number of Pometick or Horign Troops in our Pay, at the lame time that our Adverfaries kept up thrirs; and that not only frunce ftill nuintund their atitional Forecs of 'Thirty Thoufand Regular Troops, and Sixty Thoufand Mititia, but cren the Republick of Holl.m.t continud to pay Twonty Thoufand Nen more than they had betore the 'roubles bogan; an Frecuce whith no bedy doutts 
doubts but they would be glad to be rici of, as foon as their own Safety, atid their Engagements towards their Allics, would pormit.

Any Diminution therefore of our Forces at this Juncture would have been deftructive to the whole Alliance; and in Regard to our own Intereft, a molt imprudent Veafure: Becaufe the Conduct of Span made it but too evident, that the foints which were likely to be moit ftrongly conteited at the Congrefs, were fuch is immediately concerned the Interett of Englum, and of England alone; I mean Givialtar, and the Prie vileges of our Trade.

The Prcliminary Articles, b; a Confrmation of all Rights and Polleficons according to former Treatios, hal indced funforionty fecured to us thefe Points; but as Spatio hath ever hat at Fieart the Recovery of Gibraltar, and as the pretended Abutes of the Afrento Trade had beon cxtremely magnify'd; and the Adranteges of there two Points to Great Britain, wer' lock'd upon with a jealous and invidicus Ere by other Powers; the spaniards thought that mthing was more likely to create a Divifion among the Allies, than the bringing of them into Quetion, in which they were extremely 


\section{(28)}

encouraged by the Oppofers of the Adminiflation, the pretended Patriots in Englarid.

Thefe Geritimen made it their Bufincts to undertuke to prore, that his late Majefty, by a Letter ho hat witten to the King of Sprin, was cngeged to reftore Gibraltar: They mule it their buline fo endeavour to fhow, that the Irivileges of the Affento Trate hat been loneded by the fraudulent Nethos of carrying it on: They induatriwaty gave it out, that neither frence nor

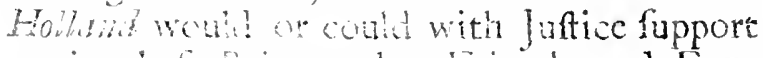
us in thefe Roints; that Friends and Enemics, nay all fiutpe, were againt us in chem; while at the fame time they vehemently inveign't againft the Minifry, as it they had not taken fufficient Care to fecure and mintain them: And thus while they themflues were the moit forward and inttrumeatal to make us lole thefe valuable Rights and Poitefions, they began to be the mor torward and fout, to complain and clamour at the Lutis oi than.

The Stondinets and Fidelity of our Allies perented the Alini of Gibrittar, and the Dipuses in Trade, from being brought before the Congres; bar hat we immediately, upon the wecting of the Congreis, resuced our Forces, 


\section{( 29 )}

Forces, and difcharged the Hefrans; had the Crown of Great Britain appeared there in a wcak and naked Poiture, entirely defencelefs and indifferent, with refpect to our own and the Pretentions of our Allies; we muit not only' have 'given up Gilinaltar and Port Mubon, but ali Benefits of Commerce which the Emperour and Spain had thought fit to demand. Could we have expered that France and Holland thould with their Power and Strength have fupported our Advantages, and fuch Advantages which it is pretended they cnry our having, while we appcarcd at the fame time not only not in a Condition and Readincfs to fecond their Pretenfions, but even deftitute of Strength and Power to fupport our own? This is fo abfurd a W'ay of Reafoning, that if it was not fo frequent in the Mouths of the pretended Patriots, it would not be worth while to mention it.

The War then was prevented; Article for putting all Rights and Poflefinus on the Foot they were before the Troubles began, had been figned ard ratify'd: But as feverel Differences and Pretenlions, whether well or ill founded, itill fubititer; as the Emprour and Spain fill continued united, the Work was but imperfes: A farther and more excenfive Treary was wanting; and confequent- 


\section{$(30)$}

Iy the fame Appearance of Steadinefs and Force that prevented a War, was neceitary to compleat a General Pacification.

What paft at the Congrefs, from the Opening of it to the framing of a Project of a Provifional Treaty, is not very material to the prefent Purpofe. Upon the Whole, the Union and Firmners of the Allies in Force and Councils, diverted the oppolite Party from bringing before the Congreis any Matters of great Importance, or from pretending to content with them any of their known Rights and Privileges; and the Imperial Plenipotentiaries were drawn by $\mathrm{De}$ grees into a Separate Negociction of a Plan for a General Treaty; and this was managed in fuch a Nanner, that the Spanis Ambarfajors were fcarce apprized of $\mathrm{it}$, which made them think themfelves, and the Intereft of their Miftcr, neglected and abandon'd by the Imperial Ariniters: They loudly compluned of this Ufrge, and made thong and ronement Remontrances againit it to their Court. The King of span began to be alam'd; and finding by the Nature of this Negociation that a Provifional Accommodation was like to be made, and the Congrefs reparated without any thing being fix'd and accomplifind by the Imperial Court that might anfirer his Vicws in Favour of his family. 


\section{( 31 )}

Family; he extremely refented fuch a Treat ment, and by his warm Repretentations againft it to the Emperour, he prevented the Signing of that Treatr. However, the Conduct of the Imperial Miniters in thefe feparate Tranfactions, and the framing a Plan with fo little Regard to the Interest of Spain, made fuch an Impreflion upon that Crown, and occationed fo much ill Humour and Difguft; that from bitter Expottulations, Span came in a Manner to a direct Breach with the Imperial Court; which fet a Negociation on Foot between the Allies and Spair, and had the good Eiffect of faparating that Crown from the Empercur, by the happy Conclution of the Treaty of Suritic.

From what hath been faid, I think it undeniably proved, that Matters could never have been brought to fo good a Situation, if we had neglected to concert the Mfeafures, and provide the Forces we cid, or if we had haftily disbanded thom. It wou'd tane been the farre Cafe, as it when two Ammies were ranged in Battle Array, and ready to engage, and the Generals had, to pretent the Efifuion of Blood, agreed to a Parley, one of them, before he faw the Succefs of that Parley, thould have been fo wife as to disband his Army : Such, I fay, would have been cur Cafe and our Widdom, had we, 


\section{(32)}

upon Signing the Preliminarics, and upon the Mecting of the Congrefs, disbanded our Forces without waiting for the Succefs of our Negociations.

I know it will be faid by the pretended Patriots, Where are thefe Advantages of Peace and of preventing a War, if we ftill continue to be at the fame Expence as if we were actually in a War? 'Thefe Words have nothing in them but Sound; the Advantages of I'eace appear by the Security of our Poffefitions, and the full Enjoyment of our Commerce: And can the Expence of Twelve'Thoufand Hefferns; and of Four Thoufand Seven Hundred and Twenty Nine Men; which was the whole Increafe of the Britifi Forces, from the Signing of the Preliminaries to the Conclution of the Treaty of Serille, beyoidd what was kept up before the Treaty of Vienna; be compared with the great Augmentation of Forces neceffary, and the Train of extraordinary and contingent Expences unavoidable alfo, in Cafe of a War? without faying any Thing of the uncertain Succers of ims, and where and to whofe Advantage the Eients even of a fuccefsful War mighe turn.

Thefe Confiderations are fo obvious, that crery prujont and impartial Englifnmain mult conclude, 


\section{(33)}

conclude, that preventive Micafures, altho' the Operations are llow and gentle, are, to a free and trading Nation, preterable to tho dazzling Glory and Eclat of Mlilitary Actions. NTo body thinks that it is cither at plcaling or defirable thing to keep up more Forces than ufual, in time of Peace: But if our Rights and Poffefions are threatned, ve muft provide and prepare for a War, and cven risk one for the Prefirration of them; and if by the Continuation of fome more than ordinary Expence, thefo Rights and Poffeffions can be fecured until an abfolute Peace can be fettled by Negociation; it may not be the moit defirable Situation, but furely much preferable to that of $1 \mathrm{Nar}$

Thefe were the Motives and Reafons for the Augmentation and Continuation of our Forces; fince the making of the Traties of Viema and Hancici, to the Conclulion of the Treacy of Seville.

The Augmentation difppointed the dangerous Defigns ot the Them. Treaty, prevented a War, procured the liening of the Preliminaries, and the Necting of the Congrels. The Continuation of the Truops during the Congrefs, cravied the Miniters of the Allies to turn the Negociations to cheir Adrantago; to Reparate Srain from $\mathrm{E}$ the 


\section{$(3+)$}

the Emperour; to diffolve the Treaty of Iiema and to re-efrablith our l'offetions and Privileges of Trade upon their ancient Fout, by the Conclufion of the Treaty of Serclle.

It comes next to be confidered, why after thefe Adrantages obtained, it is neceffary to kecp up any longer more Forces than ate ulual in Time of an abfolute Ieace.

Eut it my not be improper to obferve fnet, that upon the Conclution of the 'Treaty of lowlte, there was an immediate Recuevion of atove fire Thoufand Men of our Brith Forces; altheugh the reft of our Allies, as weil as our Adrerinics, thought fit to contine the fane Number of augmental frece, as they hat on foot betore the mang of that 'I reaty : So that we kept in on Par no mus than the Twelve Thoufind H.this, borond what we had before chele 'Thutles segan; and thoy were conti-

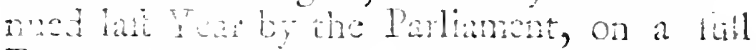

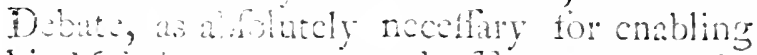
his Nifity to sxecute the Engegnome ho was und by the leaty of sivilit.

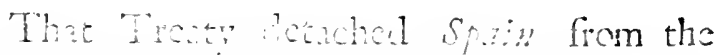

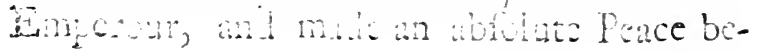




\section{$(35)$}

tween that Crown and tha Allies of How noveri.

But the Allies of Hetrerer, on the otherhand, in return for the grant Advantages they mult seap from the Accelfon of sp.hin to their Interest by learing the Emperour, were obliged by an Article of that Iraty to facurc the Sue cellion of Dcu Curtes to Tufur. ari Parim,

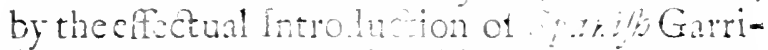

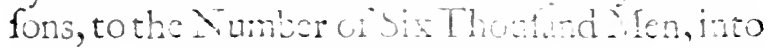
the principal Maces et thefe Dathice. 'Lhis

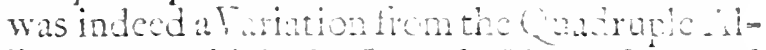
liance, by whicit the totphenen or neutral

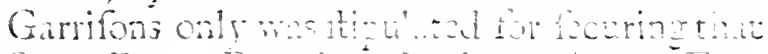

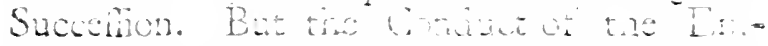

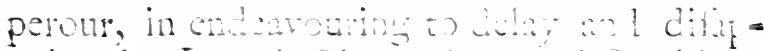

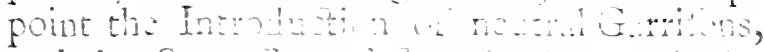

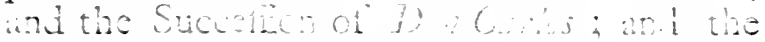
Sreps trken whe that lizw in the i us,

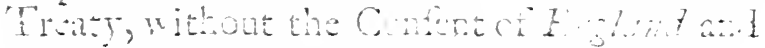

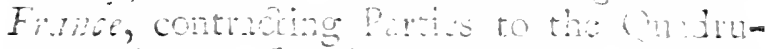

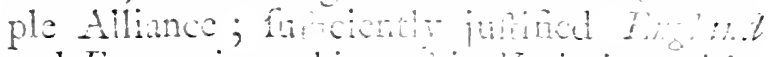

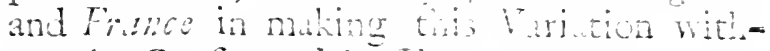
cut the Confene of the Eimporuar.

Jowne the Emperon mate we of this

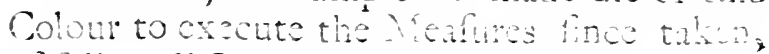
of filling all It.ty with Importal Troops; and.

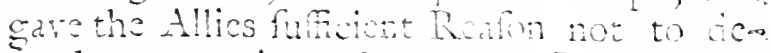

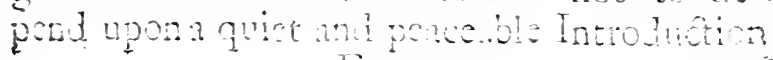
$E ?$ 


\section{$(36)$}

of 5panjo Troops into Tufany and Parma, without being in a Condition to exccute this Article by Forec in Cafe of Refintance; and confoquently male them think it necellary to keep a fuficient umber of Troops on Foot or that Eind. Our Allics therefore kept up thoir cxtroninary Levies; and furely, if the Arantages of the Treaty of Serille be conideres is they immediatcly concern this Nation, no befy unil fay but that we were nujer an camal Obligution with them, to be in a R R Rinefo to crecute an Article of fo such Inipotane: Put the Neceflity and Prubace of the beafure, will more plainly appear from the blowing Confiderations.

Ift. As to the Emperour, his Confent or Acquiefecnce muth be obtained by way of Negraciation o: Force.

That of Negrociation was certainly the mot premble $1 \mathrm{hy}$, provided it was mamaged in farh a Mnner as not to give Spain any jut Ration to complain, or reproach us with being ditary or backward in fulfilling our Enengante. But it would have been the vandt of all Imagnations, for us to hope that the Emperouir would comply on any Tems, though icry atrantageous to him, while at the fure time, wo fhould appear deftitute of the Burer and Mons to make him appre hend 


\section{( 37 )}

hend the dangerous Confequences of a Refufai.

The Scparation of Spain from the Emperour, anit the Birth of two Princes in Fratsce, had made a coniderable Altcration in the Affairs of Eirope, fince the Conclution of the Treaty of Viemal and might put it in the Power of the Hariover Ailics, without any Danger to the Balance, to offer to the Emperour fuch Provitions for his future Security, as might remove all Apprehentions from the Adurifion of any spanizh Trops into Italy; and be a I emptation to him to confent to that Introduction; provided he was convincel, at the fame time, that the Allies werc able, by the Number of their refpective Fores on Foot, to effectuate it without his Conlent. But if his Imperial Majeity had found that Eighlon had disbanded all her cxtraudinary Fores; the Confcquerice of fuch an Indifference on our Part, with refpect to the Hancer Alliance, and to the Treaty of Scilite, mutt have cincouraged the Emperour to refufe the moft tempting Oriors, and to wait patiently for the Event of Things: rather than confent upon aily T'cims, to fecure the Succelfion of Don Carlos, by the Adminon of Spanis Garrifons into the Places of 'Tufarly and Puinct? 
If therefore the kecping up thefe Forces was neceffary, cren in Cate of a Negotiation with the Emperour, and that the Allies thould have made lim any advantageous $O F$ fers to conicnt to a peaceable Introduction of Six Thoufnd Spanards into Italy; much more would they be necefiary, in Cafe the Finperon thould refolve, in all Events, and at all Hazards, to oppofe the Admifion of thole Troops; and confequently the Allies fhould bo obliged to execute their Fngagementis on that Head to Sptin, by Force: As they ccitainly mut in Honour do, if the Inperial Court thould any longer prefevere in fanding out.

ahy. We are obliged to continue there If Allics; with whom we are cqually concerned to Blifl the Ereaty of Sevilie. France and Holind wore Partics with us in the Treaty of Enpow : had poincd their. Forces and Bentures with ars, for actating the Defigns of cint of riens, and for preventing a Uar: By their Comeils and Fimners nited with ours, the Alliance between the Emmerour and sptin was difiolved; by their Affitance and Guarancy we obtained an abfolute Peace with Sprin, and a Renewal and Confunation of all our bumer Rights and 
Polfeffons; for thefe Confuerations they readily concurred with us, to promife that Crown the Introjuction of Sprizip Garrifons for fecuring the Succolition to Dor Carios: And in Order to make gool thele Promifes, and to complete the great Work of a Gencral Pacification, thoy hate though fit to keep up the fame Number of Trocps as they had before the Conciution of the Treaty of Serille. And can it be faid with any Colour of Senfe or Juntice, that we thould cntirely cisband ours; that we thould oxpect to rap alone the Advartages of thefe fuccefsiul Xegociations, and of a porfoce Peace, leaving the Expence of exacting the Articles ftipulated in Bchate of sum to our Allies; white by the Nature ch the Treaty of Seville, it is plain, that the Interat of Great Britas, in all Rofeceto, is nt lewt as much concerned as the inture? of any cthr of the Allies, to have ait the Articies of tant Trenty entireiy fulfled ?

Gly. With Rafpect io Stain; who bath a Right to demand of us the Execution of the 'Treaty of seculie', U! tho Intreduction of spanijo Garrifors.

As foon as Spainhad accoeded to tire Cundruple Alliarce, Dry Curbs hat a Kight

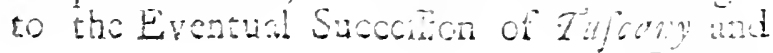
Intriat 


\section{$(40)$}

Parma, and to have that Succeffion fecured to him by neutral Garrifons. It was on this Condition, that thofe Dutchics were declared Fiefs of the Empire; and this was the Price and Equivalent for giving Sicily to the Empcrour. T'en Years palled without Spain's bcing able to obtain this Security, while the Emperour hath enjoycd all this while the Equivalent for it; and had the Grand Duke died in the mean time, thofe Dutchies would in all Probability have fallen into the Emperour's Hands; an Event as little to be delired by England, as by Spain.

Thus Matters ftood, when Span being brought to a Temper of negociating with the Allies, ofiers to abandon entirely the Imperid Court, to quic her valt Expectations from thence, and to cnter into a ftrict Uni- en with the Hanower Allies; provided they will fecure that Succelfion, that had been fo long fipulated in Favour of Don Carlos by Spanth Garritons; Time and Experience baving thewn, that the depending upon neutral Garrifons for that Purpofe, was a very dilatory and precarious Expedient. The Allies readily agrec to this Point, as being necefary for the cifcesual Security of that succelson, and juftinable with refpect to the Enpcroul, who for 10 many Years, and 


\section{(4i)}

in Breach of the Quadruple Alliance, was ufing all poffible Means to defeat it. On this Confideration, an abfolute Peace is made bctween us and Spain; all our Rights, Privileges and Pofiefions are renewed and confirmed; reafonable Stipulations are madc for Reparations of part Damages; and the trongeft Obligations giren for pucting our T'rade on the Foot of rormer Treatics; which Treaties arc particularly fpecified and confrrmed, under the Guaranty of France and Hollyth. This being the Cafe, could we with Reafon have expected or demanded of Spain the Execution of thefe bencficial Articles, if immediately on the figning of this Treaty we had disbanded all our Forces, aitd in a Manner declared to Spatin; that we bad got what we defired, and had no further Concern for the Performance of what had been ftipulatel for Sprin in the fume Treaty? How fatal the Confequences mut have been to Eygland, of a Conduet fo deftitute of common Honefty, and common Senfe, are too evidenc to want any Explaz nätion.

It mav be here asked, But of what Ule can the Heflans be for the Execuition of the Treaty of Serille, and particularly for the Introduction of Spinin Garrifons inte $\tau_{2} u_{j}=$ rany and Parma? 


\section{$(42)$}

I fhall not pretend to determine what will be the Plan of Operations for the Execution of this Point, in Cafe a War becomes neceflary. But it is obvious to every body that has confider'd the Nature of the Alliances fubifting in Europe, and how almoft all the Powers are ranged, and engaged on one Side or the other; that fufficient Provifion muft be made for mutual Defence or Diverfion in fome Parts, while the Vigour of the War is pulled in others: That at the fame time that his Majefty and the States, and the Princes in Alliance with us, may be engaged to furnith their Auxiliary Quotas of Men, Ships, or Subfidies, as may be agreed, to fupport a forcible Attempt upon Italy, their Dominions in the Low Countries and Germany or elfewhere, may not be cxpofed to the Infults of the Imperial, Priffian, or Mufcowite Troops: 'That in Order to prevent the Emperour trom increating his Army in Italy with frefh Reinforcements from his Hereditary Dominions; or in order to oblige him to withdraw from Italy even fome of the great Number of Troops that he hath already there, it may be necentary for the Allies to form a Plan of Diverfion againft his Hereditary Dominions; and confequently the Allies muli refpectively have a Proportion of 'Troops in all Parts for their mutual Defence 


\section{(43)}

Defence againt the Emperour and his Confederates, or for a Divertion to his Forces, as the Occafion thould require: For it would be impolible, as the prefent State of Europe, and the Intereft of the refpective lowcrs are conftituted, but that a War in one Part, though in Italy, mult in a greater or lefs Degree, as the Plan of Opcrations thall be formed, affect the whole Confederacy on each Side; and therefore proper Difpolitions for Defenive or Offenfive Meafures, mult be accordingly made. As the Dutch by their Situation are more immediately expofed to the Forces of the Empcrour and of Prufia, would it be reafonable to call upon them to furnifh their Contingent towards a War in Italy, without having any Forces ready for their Defence in Cafe of an Invalion of $I_{m} m-$ perial or Pruffan Troops? And as his Majefty might expect the like Infults upon his Hanover Dominions, out of Refentment for the Meafures taken by him to make good his Engagements as King of Englund, it would be unjuit to leave him expoted as $E$ :lector, purely on that account. The fame may be faid with refpect to our other Allies; and confequently, the Twelve Thoufand Hefrans, alchough not immediately imbarked in an Expedition to Italy, for introducing spain/is Garrifons into Tuscam, would in Effect, according to the Difpofi$\mathrm{F}_{2}$ 


\section{(44)}

tion to be made for mutual Defence or Diver:fion, be employed for the lame End.

It may here be faid, Well, the H.Jians were kept up laft Year, and his Majenty was enabled to moke good lois Engagements, and it was loped that a general pacification arould be the Conlequance of this juft and powerfit Allione; but inttead of leeing the defired Effects of it, ne are no farther advanced than we were; we ftill remain in the fame Uncertainty, and muft fill be liable to the fame Expence; without any Hopes of feeing an End of it, or of enjoying the Fruits of a perfect Peact.

It is true, that the Introduction of Stanith Garrifons is not yet effectuated, and until that is done, it cannot be faid, that the Pacification of Europe is eftablifned; and it is in Confequence true, that we muft be at the fame, and may perhaps be at a greater Expence thain we have hitherto been, before that happy Period is arrived. But fuppofing that to be the Cafe, it is a Cafe of Necetfity, of common Necetfity, and we are not in a worfe Situation than our Neighbours; our Allies have continued to keep up the fame Number of extraordinary lorces, which in Proportion hath been proved to be as great as ours; we have this Year enjuyed, in all other Refpects but barejy the Charge of Tuelve 'Thowand Heform, the Benefits of i'eace. And as to the Emperour, although he hath not given bis Confrie to Spanto Garrifons, yet his Condition is much worfe than that of any of the Allies, and than it was latt Year; he hata inded loft no Towns, nor Battles, but the Nuniber 


\section{$(+5)$}

Number of Forces he hath been obliged to march from his Hereditary Countsics to fitin, and the great Charge te hath been at for all Sorts of Provifons and Amminit on, to enable them to Act, and take the Lield, have made him fufter the Inconvenisncies and $\mathrm{Ex}$ pence of an actual War, withous haring, gained the leaft Advantage's from it : His Truops were increafed beyond what they were in Time of Peace with between Thirty and Forty Thoufand Men. While he received subfidies from Spriil, that was no great Load upun him; but the Separation of that Crown from him, and his being cinfequently deprived of thofe subtidies, hath flung upon him the whole Charge of above Thirty Thoufand litn more than he was able to maintan in Tine of Peace. An intolerable Burthen to a linise that is fo deftitute of Refources for Mones: His Arrempts to raile Money upon his Sighn Quick sllver have mifaried here, thro' the whe Provition in Parliament againt it latt Y'car, as "Neil as in Holland, by the frict Injuation givan by the States to forbid it and he hath it: the fatal Confequences of this necefitors Contition, without ftriking a Struke: His Puliok Lottery under the Guasnoy and protertion of the Government, bath fried for cond Mlions of Florins : And if the Ban of l Pomin, the Support of that Lottery, is nut arualy Bankrupt, yet it hath certainly rery jitle Credit. The Additional forces in Ir bered the ufual Comptement there in Time f Pace, cott the Emperour, as I am crevin!y ingunten, Xine

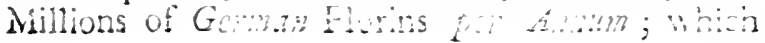




\section{$(46)$}

is about One Million Sterl. more than the fame Number coft hin in their former Quarters; over and above the Contributions paid by It.alian Princes. In the mean Time the late Revuiurion in Turkey mut have given the Emperour the greateit Unealinefs and Alam; for altho' it is not yet certain that the prefent Sulais will turn his Arms againft the Chriftians, yet the Imperial Court hath not received fich Afurances to the contrary as can make them abfolutely depend upon it; and it is agreed on all sides, that both the Venetians and Mufcovites are under great Apprehenfions of the Motions and Deligus of the Turks, which muft in no inall Degree affect the Einperour.

This is the prefent Situation of the Imperial Court; which may prove more advantageous to the Aliies, than if they had gained an actual Virtory. In this Situation is is not impoffible, but that before the Trme of Action approaches, the Emperuut may', on certain Conditions, which the Allies of Hanover may venture to grant him, now he is feparated from Spain, be difpofed to confent to the Introduction of

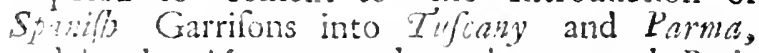
and by that Means compleat the general Pacification: But if he thould continue ftill obftinate, there is no doubt, but the Allies muft join in a proper Plan of Operations to force him to it; which if concerted with Vigour and Union among the Allics, cannos, in all human Appearance, fail of having the delired Effect.

Although this Deduction is gone into fo groat a Leighth. yer it fems necelfary, before 


\section{$(47)$}

I conclude, to remove fome Infinuations induftrioufly fpread againft the Heflan Trecps; as if they were not hired, or continued in our Pay, for the bake and Intereft of Great Britain.

The Enemies to the Government, in order to give Weight to this falfe Infinuation, have employed great Pains to make it believed, that we have been involved in the Expences and 'Troubles of late Years, purely on Account of Pretenfions and Polletions belonging to Hanover. But they tave never been able to produce one Reafon or Fat, during the Negociations and Tranfactions of fo many Years, to thew the Probability of fuch an Imputation : And if I am rightly informed, not one Word had paffed for fome Years, before the Conclufion of the Treaty of Vienna, about Bremen or Vebrden; and at the Time of making that Treaty the late King, as Elector, had not, nor hath his prefent Majefty, in that Quality, any Diffe-s rence or Difpute about any Pofleffion, with any Prince or State whatever.

It is indeed true, that fince the Conclufion of the Vienna Treaty, and that his late and prefent Majefty refolutely fupported the Honour and Intereft of the Brititb Crown and Nation, and would not make them fubferviene to the ambitious Views of other Powers; and that the Emperour could nor find that Submiffion from the King of England which he expected from an Elector; Defigns have been framed againt his Electoral Rights and Dominions, upon Points in Appearance of no 


\section{(48)}

great Confequence to the Alliances now fubfifing, or to the Affairs of Europe: And therefore formed with this artiul View, only to put his Majefty unier a Necetlity (which every good Prince mut be under in like Circumftances) to confult the fafety and Prefervation of his Honorer Dominions; and from the Meafures taken for that ilurpofe, to raife a Jealoufy in the People of Einglent, that the Quarrel is purely Electoral, and that Fingland ought to be no wife concerned, nor take any Share in it.

But his Majefty was refolved, notwithftanding any Menaces or Danger that threatned him as Elector of Hancier, not to give up the Intereft of Englond; and the Parliament being convinced, that whatever he thould fuffer in his Electoral Capacity, murt be the Effect of Refentment, for his Majefty's fteady Adherence to the Good and Honour of this Nation, came to the following Refolution.

"That in Gufice and Vindication of the "Honour of the Britin Crown, they would ef. "fectully fecind by and futport his Majefty", " a raing all Tifults and Altacks, that any" "Prime, in Reseninent of tiso juft Meafures "rkib His Mrejelty had fo wifly taken,

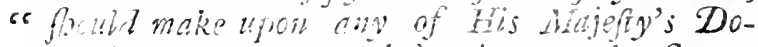
"s mincus, thenthe not belonging to the Crown " of Great Britain".

A R.folution founded upon the Rules of commo futce and mutual befence; for if the

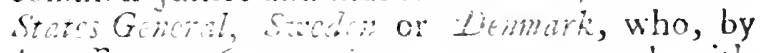
Accefion or Comentim, were engaged with the 


\section{( 49 )}

the Hanove; Allies, had been attacked by any of the Confederates of the Vicnna Treaty, the reft of the Honover Allies would have been obliged to have been concerned in the Defence of their Friend fo attacked: England and Fraince, and each of the Allies, on their Side, mult have looked upon it as a Common Caufe; and it would be moit sbfurd to fuppofe, that the Parliament of Giest Britain would not confent to defend the foreign Dominions of their own Sovereign, as well as thole of Siceden or Deimerk, if thofe Dominions were to be attacked on account of his being engaged in fupport of the finterefts of Great Britain; and till more unaccountable it would be, if the King thould not, in the Quality of Elector, find the fame Alfiltance from the Britifis Nation, as he would be fure of having, if he were Elector only, and not King. And if we will but confider the Electorate of Hanover as an Ally of Great Britain, under the Engagements of mutual Guaranties like any other Surereign State of the Empire, this Gueftion is at an End; unlefs we vainly imagine, that we may lay down fuch preporterous Rules betwixt ourfelies and 0 ther Nations, that cur Catife fhall on all Cecafrons be theirs, and that their Canfe thall never be ours. If it were neceffary to add any thing further upon this Head, I would ask thofe Gentlemen who clamour fo loudly about Hofen Truops and However Dominions; What would be the Difierence, if Hoftilities were begun in Inwnewer or in any other Part of the Wold, in Allance with us? Would not this equally be the Besmang of a general $W$ ar, and

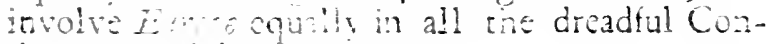
iequences ct acha itar? 
Are we not then equally obliged both in $\mathrm{Ho-}$ nour and Prudence, to prevent a War's being kindled there, as in any other Part of Europe in Alliance with us? And are we not engaged to repel and refent any Injuries, Infults, or Hoftilities begun and committed there? Unlefs we will fay, that the Elector of Hanover is the only Prince in Europe that is not to be regarded and fupported as an Ally ; and that the hing's German Dominions are the only Country that is to be expoled to the common Fate and Dangers of a Confederacy, and not to be entitled to the common Benefits of Security and Protection arifing from the fame Obligations. It is true indeed, there is no formal Alliance between Great writsin and Hanover; for the Quality of King and Elector refiding in the fame Perfon, his Majefty could not contract with himflif; but the Union betwixt the two Governments, and the Obligations of mutual Defence and Guaranty, are as ftrongly and neceffarily implied, as the moit formal 'T reaties and Conventions could poffibly make them.

To conclude the Whole, I only defire that this Controverfy may be confined to the true Mierits of the Queftion, and not be perplexed and confounded with common-place Topicks, falfe Colnurs, and Mifreprefentations: The fingle Queftion is, whether the taking the $H . f-$ fin: Troops into the Pay of Gieat Brivain, was for the Honour and Intereft of the ring and this Fingdom, And whether the continuing them, is as yet equally necellary and adviable?

Thofe 


\section{$(s \mathrm{I})$}

'Thofe who raile all the Clamour, and ftir up all the Oppofition, are very fenfible, that upon this foot, the Difpute will not bear a Moment's Debate. They therefore run from the Queftion, and harangue upon Taxes and the Debts of the Nation; upon fending fo much of our Money abroad, upon Foreign Standing Armies and Foreign Forces, paid and fupported at the Charge and Expence of this Nation, for the Sake only of Foreign Dominions. A moft abominable Practice! to reprefent a Matter of publick Confideration and publick Utility, in the mott odious and invidious Light, and in fuch a Manner, as fhall create the moft Difcontent and Diffatisfaction, where the greateft Veneration, Duty, and Affection are due. But to this Neceffity they are driven, and thefe Practices knowingly and defignedly they carry on; for they are fenfible of the fatal Tendency of thefe malicious Infinuztions; and they know very well what would be the Corfequence, if the Parliament thould not confent to continue the Feffan Troops, until the State of Publick Aftairs thall make it reafonable and advifable to difcharge them.

Let them then confers what they certainly mean, and moit certainly know, that to disband the HeTrans immediately, would be to diffolve the prefent Alliances that the King is engaged in, and at once to difcharge our Allies from all the Obligatiuns they are under to do us Juffice, and give us Satistaction with Regard to our patt Lofits and Darrages, and to fecure and confirm to us all our Rights and $p$ ielfions, and Privileges G 2 


\section{$(s i)$}

in Commerce, which we are at prefent moft juftly entitled to.

For let me fuppofe, the Parliament fhould begin with refufing to enable the King to make good his Engagements, and to raife the Quotas and Proportions ftipulated by the prefent Treaties : all Apprehenfions would at once be removed from the Emperour ; he would immediately fee the Diffolution of that Alliance that can alone bring him to Reafon : France, delerted by England, would enter into new Meafures, and think no more of executing the 'Treaty of Stville: the States of Holland, forfaken and abandoned by their ancient and natural Ally, muft confult their own. Safety and Security, and venture no more to provoke the Refentment of the Emperour, or any other formidable Neighbour.

What then would the Court of Spain do? What could they do but declare themfelves free and difcharged from all their Obligations, and at Liberty to purfue their own Views and Meafures. And is there any Englifbman that will fay, he had rather the IVorld fhould be thrown into all this Confufion, than that the Heffias Troops thould be continued ? Let them ceafe ro complain of the Diftrefs of our Trade and Commerce, the Danger of lofing Gibraltav. and Port-Makon, the Obftinacy of France in not totally demolifhing Dunkirk, who think it reafonable that we fhould at once cancel all our Obligations of Treaties.

With 


\section{(53)}

With what Face can they in one Breath re proach our Allies for failing in the minuteft Points to execute their Engagements, and call upon the Parliament of Great Britain by one Refolution to diflolve all their own? Wou!d thefe Gentlemen fpeak out, the Nation would foon judge between them and their Adverfaries. Let them tell the People, without Difguife, what Dangers and Hazards they would expofe the Nation to, if they could prevail to have the Foreign Troops disbanded in this Potture of Affairs: Let them give over the little Artifices of complaining, that we have any thing to do with the Hanvevi. Dominions; and utter their Grief plainly, That we bave any Thing to do axith the Ele ter of Hanover. And who can help thinking but that thofe, who are fo mean, in the prefent Circumftances of Things, to do the one, would readily, if it were equally fafe for them, do the other. I mean thofe who are the chief Authors and Promoters of this furious Clamour againt the Hefron Troops; for that feveral well-meaning Perfons have been led away by an artful Mifreprefentation of this Puint, I verily believe. Hut if none, who have not the lame Views and Defigns with the pretended Patriots, will be drawn into the Snares that are daily laid for them, thefe impotent and malicious Etrorts to diftrels the Government at Home, will prove as vain and ineffectual as their Endearours have been in all Foreign Courts, to embarrafs and cbftruct the Meafures concerted for the Intereft and Advantage of the King and Kingdum.

$$
F I N I S
$$








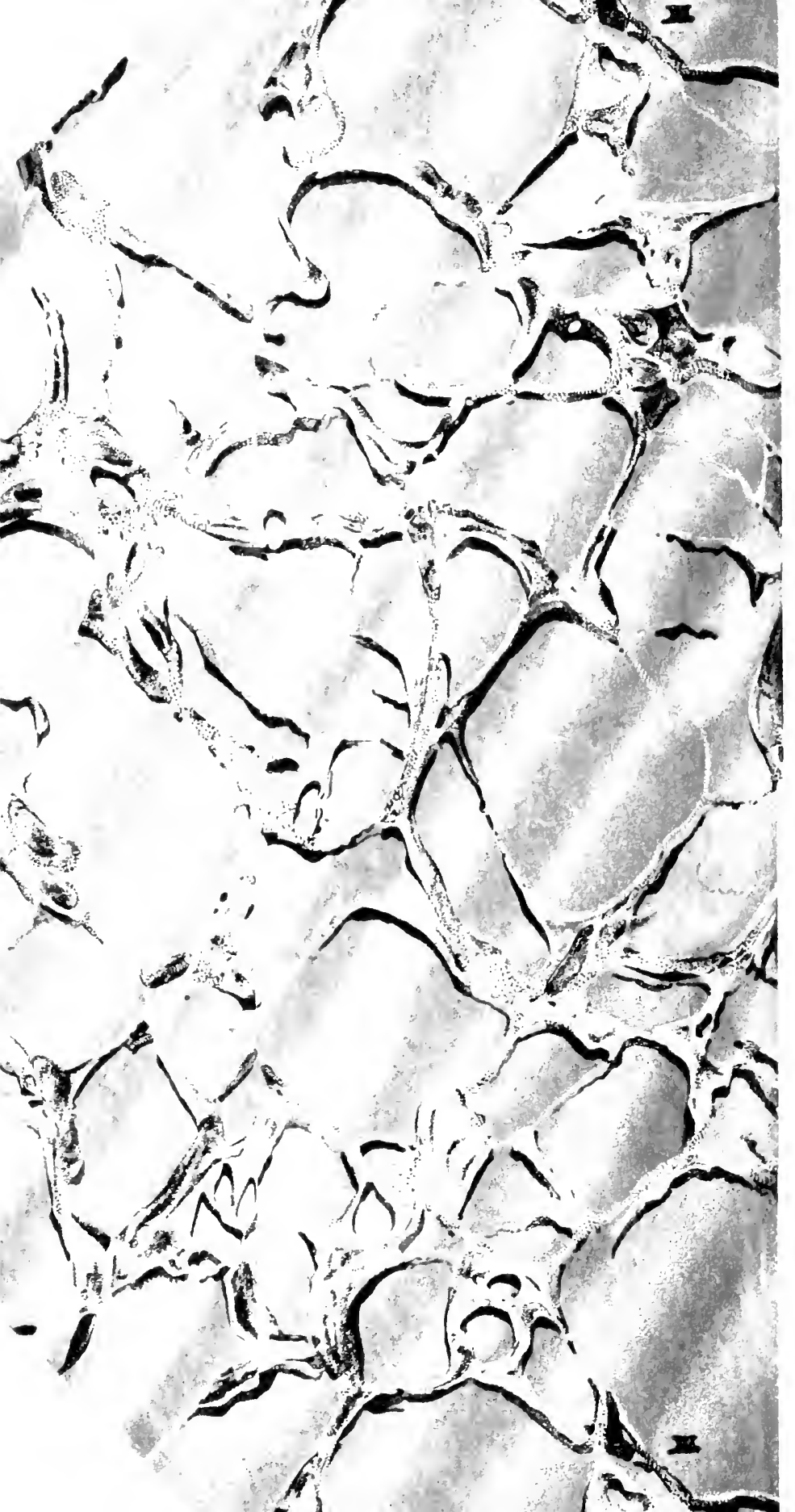

